\title{
Climate Risk Management through Sustainable Land and Water Management in Sub-Saharan Africa
}

\author{
Ephraim Nkonya, Jawoo Koo, Edward Kato, and Timothy Johnson
}

\begin{abstract}
Weather volatility is increasing, hence the need to build resilience for farmers and the poor, who are affected the most. Using Mali and Nigeria as case study countries, this study shows that climate change may reduce the yield of staple food crops - namely maize, rice, and millet - by $20 \%$ in 2050 compared to their levels in 2000. Sustainable land and water management (SLWM) - which includes a combination of organic soil fertility, inorganic fertilizer, and water managements will more than offset the effect of climate change on yield under the current management practices. Additionally, SLWM is more profitable and could therefore increase household income and address poverty.

Unfortunately, adoption rates of SLWM remain low. Policies and strategies for increasing their adoption includes improvement of market access, enhancing the capacity of agricultural extension service providers to provide advisory services on SLWM, and building an effective carbon market that involves both domestic and international buyers. The recent United Nations Framework Convention on Climate Change (UNFCCC) provides one of the opportunities for reducing climate risks and achieving sustainable agricultural production under climate change.
\end{abstract}

\section{Introduction}

Building smallholder farmer resilience in sub-Saharan Africa (SSA) is increasingly becoming an important policy agenda due to an increase in frequency and magnitude of shocks and stresses resulting from significant changes in biophysical and socio-economic factors. Food and energy price volatility, economic recession, climate change, and land degradation are the recent major changes that have increased smallholder farmer vulnerability to shocks and stresses (Torero 2015; Nazlioglu and Soytas 2012; Barrett and Constas 2014; Nkonya et al. 2016a). The global food price index increased dramatically in 2007/08 and 2011/12 and have remained relatively higher than the long-term average (Torero 2015). Rainfall variability in SSA is high

E. Nkonya $(\bowtie) \bullet$ J. Koo $\bullet$ E. Kato • T. Johnson

Environment and Production Technology, IFPRI, Washington, DC, USA

e-mail: e.nkonya@cgiar.org 
and frequency of hydrological shocks is increasing (Zseleczky and Yosef 2014). The impacts of these shocks on food security and welfare of smallholder farmers in general are enormous. Climate change is predicted to decrease production of major crops in SSA significantly. Maize production - the region's most important crop that account for $13 \%$ of cropland area (FAO 2012) - is estimated to decrease by $22 \%$ by 2050 - the largest impact among the major crops in SSA (Schlenker and Lobell 2010). Similarly, production of sorghum and millet are each estimated to decrease by $17 \%$ (Ibid). IPCC (2007) estimates a 50\% reduction in rainfed crop yield due to climate change.

In the last decade, SSA experienced the worst land degradation in the world, accounting for $22 \%$ of the total global annual cost of land degradation of about US\$300 billion (Nkonya et al. 2016b). In addition to reducing agricultural productivity, land degradation increases production risks - especially for smallholder farmers who do not use greater inputs to mask negative impacts of land degradation (Moussa et al. 2016; Nkonya et al. 2015a).

SSA countries have designed a number of policies and strategies for adaptation to climate change and to address other shocks and stressors. All 51 countries in SSA have ratified the UNFCCC and two thirds have submitted their national adaptation program of action (NAPA) (UNFCCC 2014a). In terms of mitigation, 22 SSA countries have submitted the Nationally Appropriate Mitigation Actions (NAMA) to the UNFCCC (UNFCCC 2014a, 2014b). The NAMAs are voluntary mitigation strategies designed by developing countries. They include technology, financing, and capacity-building that lead to mitigation of greenhouse gas emissions (GHG). In addition to the NAMAs, parties to the UNFCCC were asked to submit country level strategies for reduction of GHG to the 21st Conference of Parties (COP21) in Paris (Höhne et al. 2014). The COP21 GHG emission reduction strategies are known as intended nationally determined contributions (INDC). By December 2015, a total of 47 SSA countries had submitted their INDC (UNFCC 2015a, 2015b). ${ }^{1}$ All NAPAs and NAMAs/INDC mention generic land improvement action plans.

In order to design cost-effective and appropriate adaptation and mitigation strategies, policy makers and development partners need empirical evidence of effectiveness of policies and strategies for building resilience and adaptation to climate change. Accordingly, this study addresses the following major research questions:

(i) What are the impacts of climate change on production of staple foods in SSA?

(ii) What are the SLWM practices that could be used to adapt to climate change?

(iii) What is the impact of SLWM practices on production risks in SSA?

(iv) What are the drivers of adoption of SLWM practices?

(v) What are the policy implications for enhancing adaptation to climate change using SLWM practices?

In this study, we define SLWM practices as the use of soils, water, animals, and plants, for the production of ecosystem services in a manner that maintains their long-term productive potential and ecosystem functions (Liniger and Critchley

${ }^{1}$ Exceptions are Cote d'Ivoire, Mayotte, Cape Verde, \& Reunion. 
2007). Given that this definition involves complex processes, we will refer to a management practice as an SLWM when it is better than the common land degrading management practices - which largely includes no external or other organic soil fertility management (OSFM) practices that enhance soil fertility. Our SLWM practice will focus on integrated soil fertility management (ISFM) practice and irrigation. ISFM is a management practice in which appropriate germplasm is used together with judicious amounts of inorganic fertilizer and organic inputs as well as good agronomic practices (Vanlauwe et al. 2015). In addition to increasing soil carbon and thus contributing to mitigation of climate change (Vanlauwe et al. 2015), ISFM and other SLWM reduce downward production risks and increase food security (Kassie et al. 2015).

Using Mali and Nigeria as case study countries, this chapter examines the impacts of climate change on maize, rice, and millet production and risks. Selection of the countries was driven by data availability and their biophysical and socioeconomic characteristics. Mali and Nigeria represent a large share of drylands which are most affected by climate change (Christensen et al. 2007). Nigeria and parts of Kayes and Sikasso regions in Southern Mali are also in sub-humid and humid agroecological zones (Fig. 5). This further enhances the two countries' representativeness of agroclimatic characteristics in SSA.

The section below sets the context of the chapter by discussing the background of the case study countries. The discussion explores the biophysical and socioeconomic characteristics of the case study countries relevant to climate change.

\section{Background of the Case Study Countries}

We explore the general socio-economic and biophysical characteristics of the case study countries and compare them with SSA. To put into context the climate risk management, we also discuss risk management and climate change policies.

\subsection{Socio-Economic and Biophysical Characteristics of Mali and Nigeria}

With more than $50 \%$ of the population in Mali and Nigeria living below the international poverty line, the 2015 United Nations human development report puts both countries in the low human development group (Table 1). Mali and Nigeria are respectively 179th and 152th countries in the human development index (HDI) ranking of 188 countries (Table 1). ${ }^{2}$ Mali's economy is heavily dependent on agriculture as the sector accounts for $42 \%$ of the GDP and $75 \%$ of the economically

${ }^{2} \mathrm{HDI}$ is an index of life expectancy, education, and per capita gross income. HDI ranges from 1 to 0 . The higher the HDI the higher the human development. 
Table 1 Human development status in the case study countries

\begin{tabular}{|c|c|c|c|}
\hline Development indicator & Mali & Nigeria & SSA \\
\hline HDI 2014 & 0.42 & 0.51 & 0.52 \\
\hline HDI rank & 179 & 152 & \\
\hline \multicolumn{4}{|l|}{ Gross National income per capita (US\$) } \\
\hline Men & 2.195 & 6.585 & 4.148 \\
\hline Women & 961 & 4.052 & 2.626 \\
\hline \multicolumn{4}{|l|}{ Percent of population living below } \\
\hline National poverty line & 44 & 46 & \\
\hline International poverty line (PPP US $\$ 1.25$ per day) & 51 & 62 & \\
\hline Agricultural value added as $\%$ of GDP & 42 & 20 & 14 \\
\hline Agricultural share $(\%)$ of economically active population ${ }^{\mathrm{a}}$ & 75 & 54 & 58 \\
\hline Agricultural expenditure as $\%$ of total public expenditure & 13.4 & 5.2 & 5 \\
\hline $\begin{array}{l}\text { Area equipped for irrigation as share of total irrigation } \\
\text { potential }^{\text {b }}\end{array}$ & 42 & 13 & \\
\hline Ratified UNFCC? & Yes & Yes & \\
\hline Year submitted NAPA/INDC & 2007 & 2015 & \\
\hline Submitted NAMA? & No & No & \\
\hline $\begin{array}{l}\text { Savings in a formal financial institution (\% of population } \\
15 \text { years or older) }\end{array}$ & 5 & 24 & 12 \\
\hline
\end{tabular}

${ }^{a}$ For Nigeria, (NBS 2012)

${ }^{b}$ AQUASTAT raw data (Available at http://www.fao.org/nr/water/aquastat/main/index.stm)

Sources: Agriculture value as percent of GDP - World Bank (2015); Rest of the data - UNDP (2015)

active population is employed in agriculture (Table 1). For Nigeria, $54 \%$ of the 54 million economically active population is employed in agriculture - a sector that contributes $31 \%$ of the country's GDP (NBS 2012). ${ }^{3}$

In terms of investment in land-based sectors in general, Mali allocates over $13 \%$ of its public expenditure budget to agriculture (Benin and Yu 2012) - which is more than twice the SSA regional average and larger than the Maputo Declaration target of allocating $10 \%$ of public expenditure to agriculture (AU 2014). Nigeria's public expenditure budget allocation is about the regional average of 5\% and half of the Maputo Declaration target (Ibid).

As stated above, Mali and Nigeria represent well SSA's agroecological zones. The drylands areas in both countries represent a large share of SSA as 54\% of SSA land area is in the arid and semi-arid zone (Jahnke 1982) - which is home to 268 million people, $75 \%$ of which live in rural areas and are heavily dependent on agriculture (Fabricius et al. 2008). About 51\% of Mali's land area is in the hyper-arid zone (Sahara desert) while $23 \%$ and $18 \%$ is in the Sahelian and Sudan-Guinean zones respectively (RDM 2007). The share of population residing in the Sahelian and Sudan-Guinean zones are respectively $27 \%$ and $68 \%$ (INS 2009). In Nigeria the

\footnotetext{
${ }^{3}$ The oil sector accounts for $41 \%$ of the GDP. The agricultural sector includes crops, livestock, fish, and forestry (NBS 2012).
} 
Sudan Sahelian area - covering the Northeast and Northwest geopolitical zones accounts for $51 \%$ of the total area and is home to a third of the country's population (NBS 2012). The humid and subhumid areas in represent about 57\% of land area in SSA (Dixon et al. 2001), which is home to over $61 \%$ of SSA population (Fabricius et al. 2008).

\subsection{Risk Management Policies and Irrigation Development}

Savings are one of the key strategies for risk management (World Bank 2014). In developing countries, livestock serve as savings and insurance against risks. Only $5 \%$ and $24 \%$ of the population above 15 years old in Mali and Nigeria, respectively, has savings in a formal banking institution (World Bank 2014). The SSA regional average is $12 \%$ indicating that Mali is below and Nigeria is above the regional average. Nigeria represents regional average human development and above average risk management while Mali is below average for both indicators. Livestock accounts for more than $50 \%$ of capital held by SSA rural households (Kamuanga et al. 2008). However, the livestock sector's contribution to income is low because of its low productivity (Nkonya et al. 2016b). Accordingly, livestock contributes respectively 15\% and 3.3\% of Mali and Nigeria GDP (FAO 2005a, 2005b). In both countries, over $90 \%$ of the rural households own livestock - suggesting that smallholder farmers use the traditional savings and insurance mechanisms more than the formal instruments. Unfortunately, government investments in enhancing the livestock sector are quite low: the sector receives less than $5 \%$ of the public expenditure budget in SSA (Nkonya et al. 2016b).

On climate change adaptation policies, Nigeria submitted its INDC prior to the Paris COP21 in which one of its strategies for adaptation to climate change include climate smart agriculture and reforestation. The country has not yet delivered NAPA or NAMA - suggesting a weak political will to invest in adaptation to climate change. Mali has submitted its NAMA in which SLWM practices are among the adaptation strategies (RDM 2007). However, Mali has has also submitted its INDC with an agriculture-related commitment to increase rice irrigation efficiency to reduce water loss. The INDC also aims at protection of forests and reforestation to enhance carbon mitigation (Ibid).

Irrigation development is an important strategy for climate change adaptation and for enhancing food security in SSA (Burney et al. 2013). This is especially important in the drylands which will be most affected by climate change. Nelson et al. (2009) estimate that about $24 \%$ of the US $\$ 3$ billion annual investment expenditure (as of 2000) required to offset the effect of climate change on nutrition in SSA will be for irrigation development (Fig. 1).

Mali has significantly invested in irrigation as $42 \%$ of its irrigation potential is equipped for irrigation (FAO 2005c). However, the country remains highly vulnerable due to the large area being in the drylands and large share of population dependent on agriculture. Only $13 \%$ of irrigable area in Nigeria is equipped for irrigation -a 


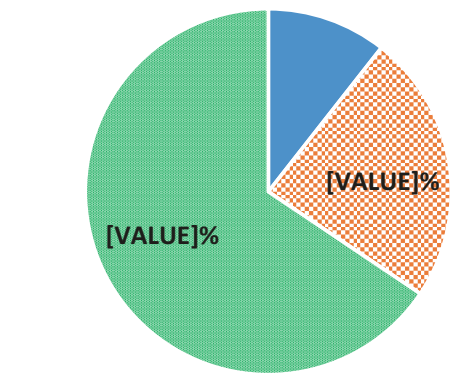

- Agricultural research \& Irrigation efficiency « roads

Fig. 1 Contribution of irrigation, roads, and R\&D to total additional annual investment (2000 US\$3 billion) required to offset the effects of climate change on nutrition in SSA (Note: Nelson et al. (2009) separate irrigation and road investments into supporting area expansion and yield increase (for roads) and enhancement of water use efficiency (for irrigation). The Percentages reported for irrigation \& roads are derived from a sum of the two groups (Source: Extracted from Nelson et al. 2009)

level that puts Nigeria among 24 SSA countries with less than 50\% of irrigation potential equipped for irrigation (FAO 2005c). However, Nigeria has invested significantly to support irrigation development in the semi-arid areas as $68 \%$ of the irrigated area in Nigeria is located in the semi-arid northern zone (FAO 2005c).

Below, we discuss the methods and data used in this study, in which we show the temporal and spatial scale of the analysis of impact of climate change on food security. In order to draw relevant policy implications and strategies required to enhance adaptation to climate change, we discuss the analytical approaches of the drivers of adoption of SLWM practices and their impacts on climate-related risks.

\section{Methods and Data}

\subsection{Impact of Climate Change on Food Security}

We estimate the impact of climate change on crop productivity in the year 2050 using climate simulation models with different assumptions that lead to optimistic and pessimistic predictions. The National Center for Atmospheric Research (NCAR) predicts greater precipitation (10\% increase), while the Commonwealth Scientific and Industrial Research Organization (CSIRO) model predicts a drier climate (2\% decrease in 2050) (Nelson et al. 2009).

Additionally, we use a crop simulation model to estimate the impact of SLWM practices on climate-related production risks with and without climate change from the year 2000 to 2050 . We also use the same model to estimate carbon sequestration since soil carbon is one of the most important elements determining adaptation and 
mitigation to climate change (Lal 2004, 2011). We use the DSSAT (Decision Support System for Agrotechnology Transfer) Cropping System Model v4.5 (Hoogenboom et al. 2010; Jones et al. 2003), which combines crop, soil, and weather databases for access by a suite of crop models embodied in one system. The models integrate the effects of crop system components and management options to simulate the states of all the components of the cropping system and the interaction between them. DSSAT crop models are designed on the basis of a systems approach, which provides a framework for users to understand how the overall cropping system and its components function throughout cropping seasons, on a daily basis. The DSSAT model has been widely used in various types of cropping systems all over the world, including low-input subsistence ones in SSA. The model was modified by incorporating a soil organic matter and residue module from the CENTURY model and this combined model, DSSAT-CENTURY, was used in this study, as it was designed to be more suitable for simulating low-input cropping systems and conducting long-term sustainability analyses in SSA (Gijsman et al. 2002).

\subsection{Drivers of Adoption of SLWM Technologies and their Impact of Climate-Related Production Risks}

We estimate the drivers of adoption of SLWM using a Probit model shown below:

$$
\mathrm{Y}^{*}=\Phi-1(\mathrm{Y})=X \beta+\varepsilon
$$

Where $\mathrm{Y}^{*}$ is a latent variable, given by:

$$
Y=\left\{\begin{array}{c}
0 \text { if } Y^{*} \leq 0 \\
1 \text { if } Y^{*} \geq 1
\end{array},\right.
$$

$\Phi$ is a normally distributed cumulative static with Z-distribution, i.e. $\Phi(Z) \epsilon(0,1), \mathrm{X}$ is a vector of covariates of determinants of adoption of SLWM practices and $\beta$ is a vector of the associated coefficients. $\mathrm{X} \beta \sim \mathrm{N}(0,1)$; $\varepsilon$ is an error term with normal distribution, i.e., $\varepsilon \sim \mathrm{N}(0,1)$.

Choice of the elements of the $\mathrm{X}$ vector in the empirical model is guided by literature $^{4}$ and data availability. Given that some drivers of adoption of SLWM are potentially endogenous, we estimate a reduced form model to determine the robustness of the coefficients. The coefficients reported in the results section show that they were generally robust to statistical errors.

Impacts of SLWM on production risks is estimated using Just-Pope meanvariance model (Just and Pope 1979) - a model that estimates deviation from conditional mean crop yield:

\footnotetext{
${ }^{4}$ Please see Nkonya et al. (2008) and Di Falco (2014) for a review.
} 


$$
Y=f(X, C)=p(X, C)+\sqrt{\varphi(X, C)} e(\xi)
$$

Where $\mathrm{Y}=$ yield which is affected by a deterministic production function $P(\bullet)$ and stochastic risk function $\varphi(\bullet)$ with an error term $(e(\xi))$ determined by rainfall and other production risks.

$\mathrm{C}$ and $\mathrm{X}$ are respectively covariates of land management practices and other covariates, which simultaneously affect $P(\bullet)$ and $\varphi(\bullet)$.

$\frac{\partial \operatorname{var}(Y)}{\partial C}>0 \rightarrow$ Risk-increasing land management practice, $\frac{\partial \operatorname{var}(Y)}{\partial C}<0 \rightarrow$ Risk-reducing land management practice.

\subsection{Data}

Plot and household level survey data were used from both countries to determine farmers' land management practices and yield. For Mali, the 2004/05 agricultural household survey data were used. The data were nationally representative and included 10,000 households. The agricultural household survey data from Nigeria were collected by IFPRI for impact assessment of a large agricultural project that covered the entire country. A total of 9176 households from all 37 states were surveyed. The 37 states formed the strata and the data were representative at state level. Unfortunately, the data collected in Mali and Nigeria were not the same and the covariates included in each country differ slightly but largely remain comparable on a broader scale.

We use three staple crops - namely maize, rice, and millet, which account for the largest caloric requirements in both countries. The three crops are staple crops in both countries and in total account for $45 \%$ and $27 \%$ of the harvested area in Mali and Nigeria respectively (FAOSTAT 2013). However, rice consumption in both countries is rising and for the case of Nigeria, the country is the second largest rice importer in the world (after China) (Johnson et al. 2013). Nigeria rice import is worth about US\$2 billion per year (Ibid). Through its agriculture transformation agenda policy, the country has embarked on achieving rice self-sufficiency by 2015 (Ibid) - a target that was not achieved.

The major soil fertility management practice scenarios simulated for maize, rice, and millet are given in Table 2. Irrigation is not shown since it is only used for rice and no scenario for rainfed rice is simulated. In all simulations, we assumed no carbon fertilization, since maize and millet are $\mathrm{C} 4$ species, which are not significantly affected by carbon fertilization (Leakey 2009). However, carbon fertilization 
Table 2 Soil fertility management scenarios used for crop simulation

\begin{tabular}{l|l|l}
\hline $\begin{array}{l}\text { Treatment } \\
\text { code }\end{array}$ & Description of treatment (scenario) & Relevance \\
\hline TR0 & $\begin{array}{l}\text { Normal practices, all zero inputs, no crop } \\
\text { residues left on farm after harvest }\end{array}$ & $\begin{array}{l}\text { Farmer practice as majority of } \\
\text { farmers in both countries don't } \\
\text { apply any inputs }\end{array}$ \\
\hline TR1 & 100\% Crop residue left on farm after harvest & Farmer practice \\
\hline TR2 & $\begin{array}{l}\text { Manure 5 tons/ha }+100 \% \text { Crop residue left on } \\
\text { farm after harvest }\end{array}$ & $\begin{array}{l}\text { First level of improved farmer } \\
\text { practice }\end{array}$ \\
\hline TR3 & $\begin{array}{l}\text { 40kgN/ha }+1.67 \text { t/ha Manure }+50 \% \text { Crop } \\
\text { residue left on farm after harvest }- \text { most likely } \\
\text { practice that farmers are likely to afford }\end{array}$ & $\begin{array}{l}\text { About half the recommended } \\
\text { application rate for maize and } \\
\text { rice }\end{array}$ \\
\hline TR4 & $\begin{array}{l}\text { 80kgN/ha }+100 \% \text { Crop residue left farm after } \\
\text { harvest }\end{array}$ & $\begin{array}{l}\text { Represents government policies } \\
\text { that provide fertilizer subsidy }\end{array}$ \\
\hline $\begin{array}{l}\text { 80kgN/ha }+5 \text { t/ha Manure }+100 \% \text { Crop } \\
\text { residue left on farm after harvest }- \\
\text { recommended practices for maize and rice }\end{array}$ & $\begin{array}{l}\text { Recommended soil fertility } \\
\text { management practice }- \text { Aduayi } \\
\text { et al. (2002) }\end{array}$ \\
\hline
\end{tabular}

Source: Authors' review

is likely to increase yield for rice (C3) and this means our estimates for rice under climate change may be underestimated.

\subsubsection{DSSAT Model Calibration}

Calibration of the DSSAT model was achieved through a process of parameter adjustment in the DSSAT default settings so that the final simulations were as close as reasonably possible to data that were reported in the literature as representing farmers' fields. Data for calibration of the DSSAT model were obtained from agricultural research institutes in Mali and Nigeria that focused on soil fertility management practices.

The weather data solar radiation, minimum and maximum temperatures, and rainfall were generated using stochastic functions based on historical weather data obtained from WorldClim http://worldclim.org; Hijmans et al. 2005). For the base climate scenario, the WorldClim current conditions data set, which are an average of 1950 to 2000, and which reports monthly average minimum and maximum temperatures and monthly average precipitation, are used. Precipitation rates and solar radiation data were obtained from NASA's LDAS website (http://ldas.gsfc.nasa. gov). The future rainfall data (2000 to 2050) were obtained from CSIRO (Commonwealth Scientific and Industrial Research Organization) and NCAR. All average climate variables were generated at a $10 \mathrm{~km} \times 10 \mathrm{~km}$ grid scale. In order to decrease the simulation workload, only projections under the IPCC (Intergovernmental Panel on Climate Change) scenarios a2 and 2050s (corresponding $\mathrm{CO}_{2}$ concentration of $599 \mathrm{ppm}$ ) are used. 
Soil profile data were obtained from the FAO harmonized soil profile database. ${ }^{5}$ Topographic data were obtained from the HydroSHEDS database - a global topographic database derived from NASA's SRTM (Shuttle Radar Topography Mission) data and contains 90 m hydrologically conditioned digital elevation model (DEM) data.

On water management, farmer management practices are reflected by using rainfed scenarios for maize and millet and irrigation for rice. In Nigeria, 52\% of rice production is under lowland flood irrigation and $16 \%$ under fully equipped irrigation (Johnson et al. 2013). In Mali, 50\% of rice production is under equipped irrigation (Ministère de l'Agriculture (2009) and about 68\% of farmers use some form of irrigation for rice production (Dillon 2008). In both countries, maize and millet are almost entirely rainfed.

\section{Results}

\subsection{Impact of Climate Change on Crop Yield and Food Security Implications}

In both countries, maize and rice yields are significantly reduced by climate change. Table 3 shows that between 2000 and 2050, yields of maize and rice are expected to decrease by $3 \%$ to $39 \%$ depending on the climate change scenario used. Yield of all three staple crops would decrease under both the NCAR and CSIRO models. As expected, yield reduction under CSIRO is greater than is the case under NCAR. Decrease of millet is the lowest - underscoring its resilience in the drylands. The maize and rice yields in both countries have a greater decrease for treatments receiving inorganic fertilizer than those which do not receive the treatment (Tables 3 and 4). This could be due to the higher variability of high input production systems under climate stress. Rainfed millet yield will decrease the least due to its resilience to dry conditions.

The results show an average decrease of about $21 \%$ of staple food production suggesting a reduction of household food security. This is especially high under farmer management practices, which are already lower and will decrease further even without climate change. Additionally, the results show different crop response to climate change and the need to emphasize crop diversification among farmers as one of the strategies for climate risk management.

\footnotetext{
${ }^{5} \mathrm{http} / / / \mathrm{www}$. fao.org/soils-portal/soil-survey/soil-maps-and-databases/harmonized-world-soildatabase-v12/en/.
} 
Table 3 Maize, rice, and millet yield in 2050 under different climate change scenarios, Mali

\begin{tabular}{|c|c|c|c|c|c|c|}
\hline & TR0 & TR1 & TR2 & TR3 & TR4 & TR5 \\
\hline \multicolumn{7}{|c|}{ Yield (tons/ha) } \\
\hline \multicolumn{7}{|c|}{ No climate change } \\
\hline Maize $^{\mathrm{a}}$ & 0.4 & 0.5 & 0.7 & 3.4 & 1.7 & 3.6 \\
\hline Rice $^{b}$ & 0.6 & 1.6 & 1.3 & 6.4 & 3.5 & 6.8 \\
\hline Millet $^{\mathrm{c}}$ & 0.4 & 0.4 & 0.3 & 0.4 & 0.4 & 0.4 \\
\hline
\end{tabular}

Climate change: NCAR

\begin{tabular}{l|l|l|l|l|l|l}
\hline Maize $^{\mathrm{a}}$ & 0.34 & 0.48 & 0.63 & 2.72 & 1.43 & 2.87 \\
\hline Rice $^{\mathrm{b}}$ & 0.45 & 1.19 & 0.91 & 4.65 & 1.77 & 5.01 \\
\hline Millet $^{\mathrm{c}}$ & 0.39 & 0.38 & 0.32 & 0.37 & 0.32 & 0.39 \\
\hline
\end{tabular}

Climate change: CSIRO

\begin{tabular}{l|l|l|l|l|l|l}
\hline Maize $^{\mathrm{a}}$ & 0.38 & 0.50 & 0.69 & 3.03 & 1.58 & 3.25 \\
\hline Rice $^{\mathrm{b}}$ & 0.67 & 1.48 & 1.07 & 4.93 & 2.04 & 5.20 \\
\hline Millet $^{\mathrm{c}}$ & 0.40 & 0.39 & 0.34 & 0.42 & 0.40 & 0.50 \\
\hline
\end{tabular}

Impact of climate change on yield (Percent change) ${ }^{\mathrm{d}}$

\begin{tabular}{l|l|l|l|l|l|l}
\hline Maize $^{\mathrm{a}}$ & -13.3 & -2.7 & -12.0 & -16.3 & -19.3 & -19.1 \\
\hline Rice $^{\mathrm{b}}$ & -20.2 & -31.0 & -33.9 & -37.3 & -35.6 & -34.0 \\
\hline Millet $^{\mathrm{c}}$ & 6.3 & 2.1 & -0.8 & 5.7 & -3.6 & -1.9 \\
\hline
\end{tabular}

Note: see Table 2 for definition of Treatments TR0-TR5

Sites: ${ }^{\text {a Sikasso, }}$

${ }^{\mathrm{b}}$ Segou

${ }^{\mathrm{C}}$ Cinzana

d $\frac{N o \_C C-\overline{C C}}{N o \_C C} * 100$ where No_CC $=$ No climate change, $\overline{C C}=$ average yield for NCAR \& CSIRO models

\subsection{How Much Does SLWM Help Reduce Impact of Climate Change on Crop Yield?}

We compared the yield of crops with and without SLWM under climate change to determine the level at which SLWM could help reduce the impact of climate change. The impact of SLWM practices on climate adaptation strategies offers some insights on the options that farmers could use to adapt to climate change. For brevity, we only compared TR3, i.e., 40kgN/ha, 1.67 t/ha Manure and 50\% crop residue (TR3) which could be regarded as an ISFM practice since $40 \mathrm{kgN} / \mathrm{ha}$ is half of the recommended amount of $80 \mathrm{kgN} /$ ha (Table 2). We compare T3 with the average yield of farmer practice (TR0 \& TR1). Figure 2 shows that SLWM practices are predicted more than double the yield of maize and rice under farmer practice in both countries. This means SLWM could not only offset the negative impact of climate change but could increase yield under farmer practice. The results underscore the importance of promoting SLWM practices as a strategy for addressing climate change. 
Table 4 Maize, rice, and millet yield in 2050 under different climate change scenarios, Nigeria

\begin{tabular}{l|l|l|l|l|l|l}
\hline & TR0 & TR1 & TR2 & TR3 & TR4 & TR5 \\
\hline \multicolumn{7}{l}{ Maize } \\
\hline No CC & 1.03 & 1.32 & 1.58 & 4.32 & 3.26 & 4.33 \\
\hline NCAR & 1.0 & 1.2 & 1.4 & 2.6 & 3.4 & 3.4 \\
\hline CSIRO & 0.9 & 1.1 & 1.6 & 2.3 & 3.1 & 3.1 \\
\hline Average & 0.9 & 1.1 & 1.5 & 2.5 & 3.3 & 3.2
\end{tabular}

\section{Rice}

\begin{tabular}{l|l|l|l|l|l|l}
\hline No CC & 1.12 & 2.79 & 1.98 & 9.49 & 4.33 & 10.24 \\
\hline NCAR & 1.0 & 2.3 & 1.4 & 3.5 & 7.8 & 8.8 \\
\hline CSIRO & 0.9 & 2.2 & 1.6 & 8.1 & 3.5 & 8.9 \\
\hline Average & 0.9 & 2.3 & 1.5 & 7.9 & 3.5 & 8.9 \\
\hline
\end{tabular}

Millet

\begin{tabular}{l|l|l|l|l|l|l}
\hline No CC & 0.71 & 1.22 & 1.27 & 1.38 & 1.22 & 2.31 \\
\hline NCAR & 0.7 & 1.1 & 1.2 & 1.1 & 1.0 & 1.7 \\
\hline CSIRO & 0.6 & 1.1 & 1.1 & 1.2 & 1.0 & 1.8 \\
\hline Average & 0.6 & 1.1 & 1.1 & 1.2 & 1.0 & 1.8
\end{tabular}

\section{Impact of climate change on yield (Percent change) ${ }^{\mathrm{a}}$}

\begin{tabular}{l|l|l|l|l|l|l}
\hline Maize & -8.5 & -13.2 & -5.7 & -24.6 & -23.5 & -25.9 \\
\hline Rice & -18.4 & -19.4 & -23.8 & -16.4 & -18.8 & -13.5 \\
\hline Millet & -9.2 & -9.9 & -10 & -15.2 & -15.5 & -22.7 \\
\hline
\end{tabular}

Note: $\frac{N o \_C C-\overline{C C}}{N o \_C C} * 100$ where $N o \_C C=$ No climate change, $\overline{C C}=$ average yield for NCAR \& CSIRO models

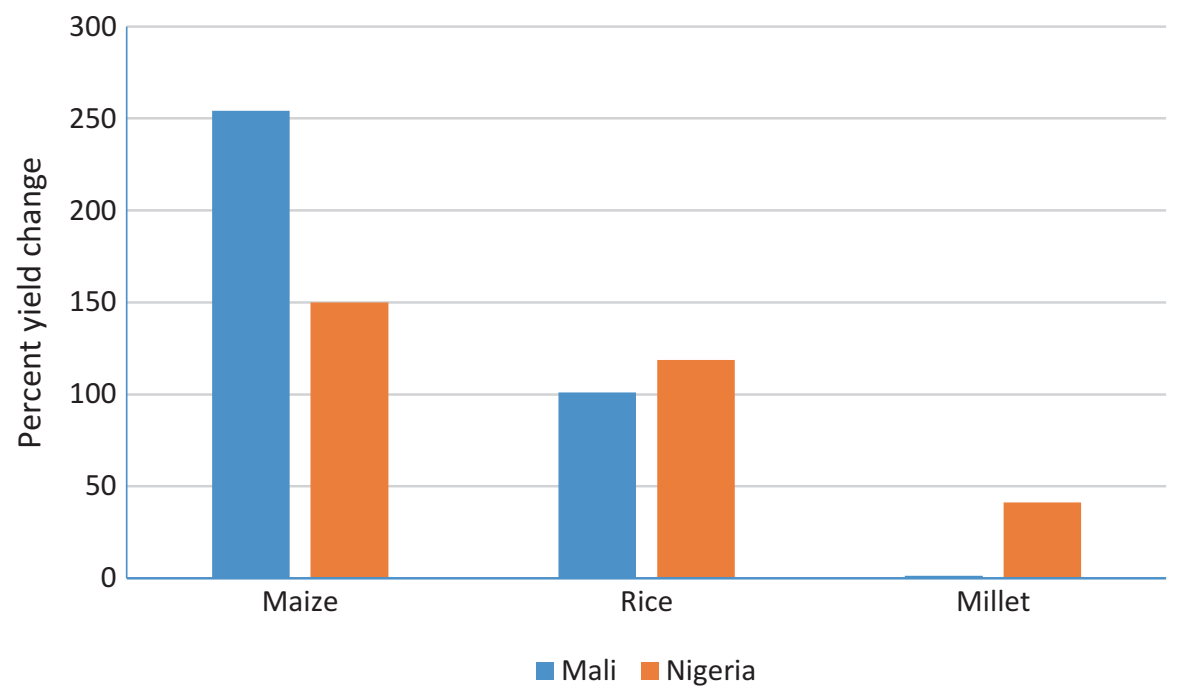

Fig. 2 Change of crop yield under farmer practice change under climate change due to use of SLWM practices 
It is important to examine SLWM adoption rate and drivers of adoption in order to identify the appropriate polices and strategies for enhancing their adoption. The next section addresses these important questions.

$$
\Delta y=\frac{y_{1}-y_{0}}{y_{0}} * 100
$$

Where $\mathrm{y}_{1}=\mathrm{T} 3$ yield $\& \mathrm{y}_{0}=$ average yield of T0 \& T1 under climate change (see Table 2 for definition of T0, T1 \& T3).

\subsection{Adoption Rate of SLWM Practices}

About $50 \%$ of farmers in SSA do not use external inputs such as inorganic fertilizer or organic inputs (Table 5). Adoption of inorganic fertilizer and organic inputs are respectively about $19 \%$ and $25 \%$ (Table 5). Pender et al. (2009) observed lower adoption rates of external inputs since they observed that only $3 \%$ of farmers in SSA use low-cost productivity enhancing management practices - such as organic inputs. The low adoption of organic inputs is especially troubling given that it could be produced by farmers and is crucial in reducing climate-related production risks.

Even though irrigation could increase crop yield by at least $50 \%$ (Ringler and Nkonya 2012), its adoption is only 7\% (Table 5) - an aspect which illustrates the weak irrigation development in SSA (You et al. 2011). As discussed earlier, irrigation development is one of the key investments required for adaptation to climate change in SSA (Nelson et al. 2009) and its low adoption rate underscores the urgent need for increasing investment and promoting its adoption.

More detailed analysis for the case study countries shows an interesting pattern. About $6 \%$ of crop farmers in Mali and 12\% in Nigeria use irrigation (Figs. 3 and 4). There is large variation of adoption of irrigation in both countries across

Table 5 Adoption and profitability of soil fertility management practices in SSA

\begin{tabular}{l|l|l|l|l|l}
\hline \multirow{2}{*}{ Country } & ISFM & Fertilizer & Organic inputs & Irrigation & Nothing \\
\cline { 2 - 7 } & \multicolumn{2}{l}{ Adoption (percent) } & \multicolumn{2}{l}{} \\
\hline Mali & 18 & 16 & 39 & 6.0 & 27 \\
\hline Uganda & 0 & 1 & 68 & 0.1 & 31 \\
\hline Kenya & 16 & 17 & 22 & 2.0 & 44 \\
\hline Nigeria & 1 & 23 & 28 & 12.0 & 47 \\
\hline Malawi & 8 & 52 & 3 & 2.3 & 38 \\
\hline Tanzania & 1 & 1 & 3 & 3.6 & 95 \\
\hline Average adoption rate and profit & 6.2 & 19.1 & 24.6 & 7.0 & 49.8 \\
\hline Adoption rate (\%) & 36.5 & 24.6 & 15.1 & & 10.4 \\
\hline Profit (US\$/ha/year) & & & &
\end{tabular}

Source: Nkonya et al. (2016a) 


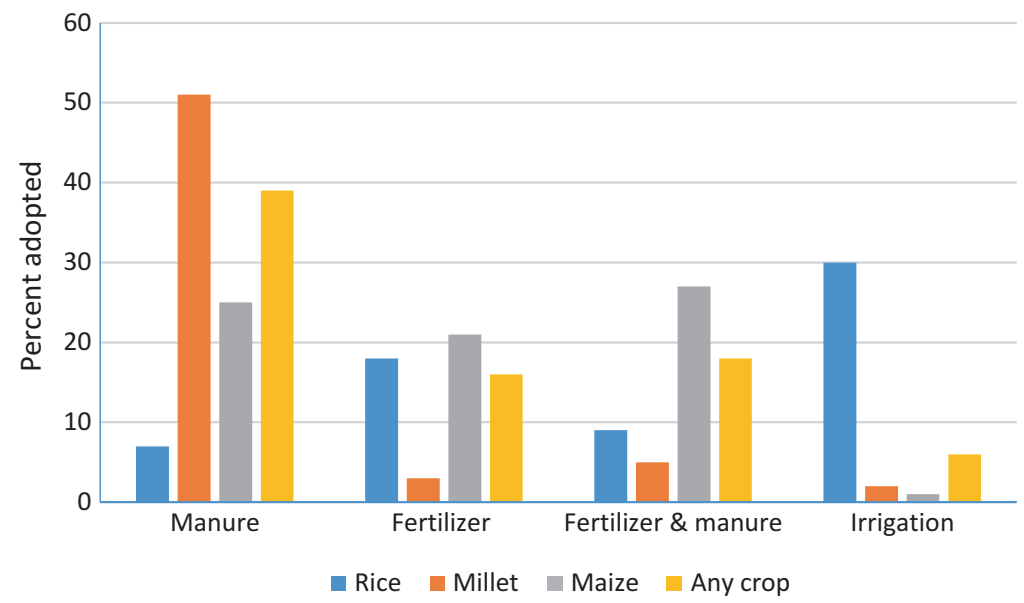

Fig. 3 Adoption rates of manure, fertilizer, and irrigation in Mali. Source: computed from raw data, Mali agricultural census 2004/05

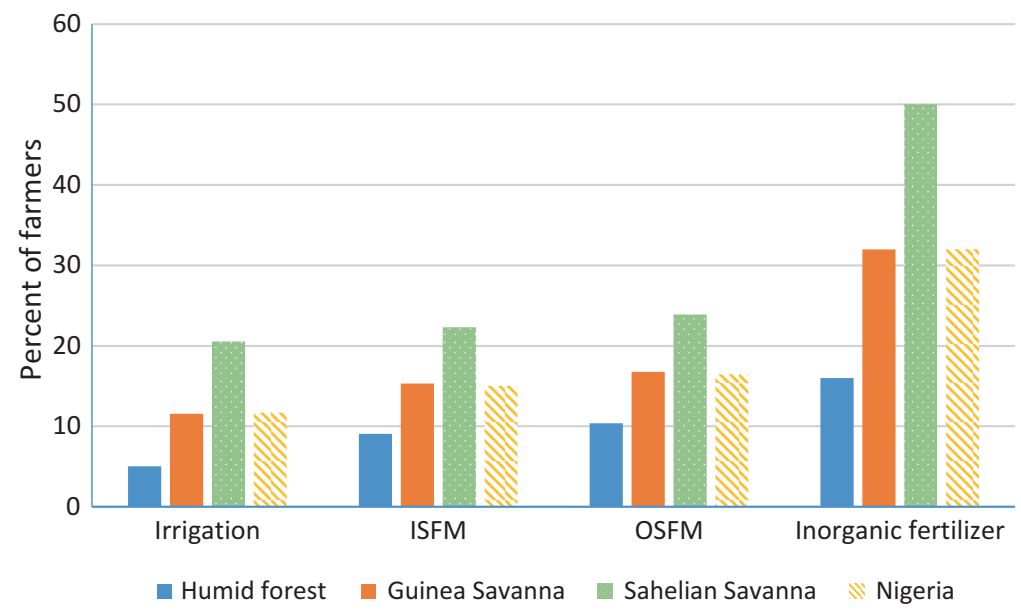

Fig. 4 Adoption rate of soil fertility management practices, Nigeria

agroecological zones and crops. Drylands account for the largest share of irrigated area. About $30 \%$ of rice is irrigated in Mali (Fig. 3), a level that reflects the dominance of rice as an irrigated crop in Africa. About $14 \%$ of the area under full or partial control irrigation in Africa is planted with rice (FAO 2005). On spatial distribution, irrigation is concentrated in the drylands in both countries. About $70 \%$ of irrigated area in Mali is in the Sahelian zone located in the middle belt (Fig. 5). Likewise, adoption of irrigation is highest in the Sahelian Sudan and Guinea Sudan in Nigeria (Figs. 4 and 5), both of which account for 68\% of irrigated area in Nigeria (FAO 2005). 


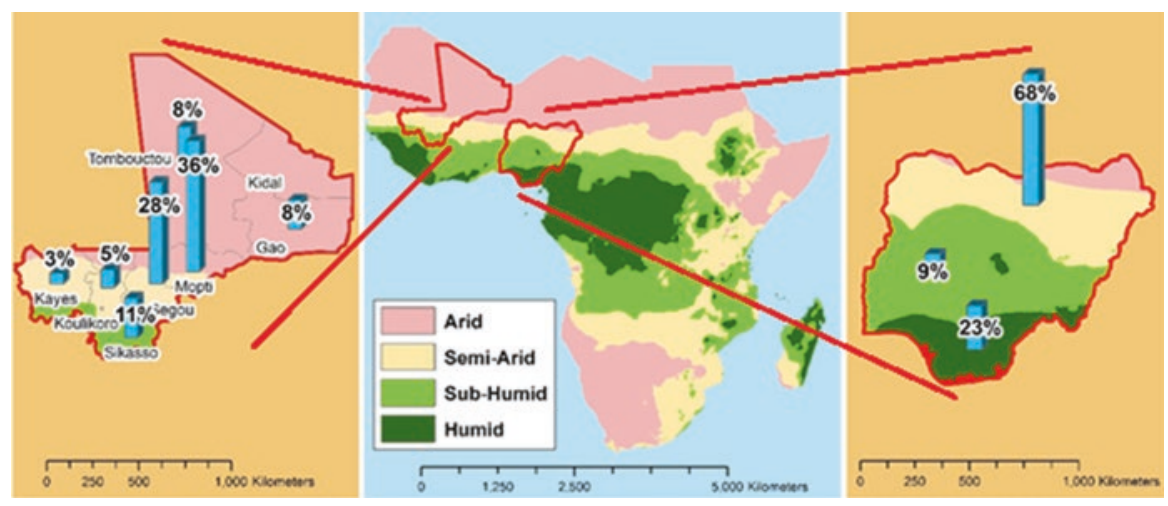

Fig. 5 Distribution of irrigated area across agroecological zones, Mali \& Nigeria (Sources: RDM (2009) and FAO (2005))

Adoption of OSFM is very high in Mali but quite limited in Nigeria. Over 50\% of millet farmers in Mali apply manure and 39\% of all crop farmers in the country apply manure (Fig. 3). This level is much higher than the adoption rate of inorganic fertilizer - which is only $16 \%$. In Nigeria, only $16 \%$ of farmers apply OSFM practices, which includes animal and green manure, agroforestry, and composting. Adoption of inorganic fertilizer is much higher (32\%) (Fig. 4). One of the reasons behind such high adoption of inorganic fertilizer could be the high fertilizer subsidy rate and relatively higher income of farmers in Nigeria compared to those in Mali (Table 1). Adoption of ISFM is $18 \%$ and $1 \%$ in Mali and Nigeria, respectively (Table 5) - and in both cases lower than less profitable practices (Figs. 3 and 4).

Given the adoption patterns of soil fertility management practices discussed above, it is important to analyze the adoption incentives and drivers of their adoption. To better understand the adoption incentives and competitiveness of the land management practices, the section below analyzes profitability of soil fertility management practices in the case study countries. This is followed by analysis of the drivers of adoption of soil fertility management practices, which will be used to draw implications on policies and strategies for increasing their adoption, and consequently enhancing adaptation to climate change.

\subsection{How Profitable Are the SLWM Practices?}

Soil fertility management practices that combine manure and inorganic fertilizer or ISFM (TR3 \& TR5) generally have the highest profit for all crops (Table 6). This is consistent with other studies (e.g. Doraiswamy et al. 2007; Sauer et al. 2007; Nkonya et al. 2016a). The predominant management practices (TR0 \& TR1) regarded in this study as farmer management practices - are least profitable, and are shown to have greater yield variability. 
Table 6 50-year average profit of soil fertility management practices with no climate change

\begin{tabular}{c|l|l|l|l|l|l}
\hline \multicolumn{7}{l}{ Soil fertility management practices } \\
\hline Country/crop & TR0 & TR1 & TR2 & TR3 & TR4 & TR5 \\
\hline & US\$/ha \\
\hline Mali & 13.34 & 15.72 & 20.05 & 126.57 & 52.53 & 127.16 \\
\hline Maize & 109.53 & 128.09 & 248.66 & 383.39 & 72.74 & 494.63 \\
\hline Rice & 8.88 & 9.65 & 16.05 & 14.72 & 13.21 & 20.90 \\
\hline Millet & 206.13 & 295.98 & 451.41 & 881.51 & 904.52 & 1142.46 \\
\hline Nigeria & 66.93 & 115.78 & 96.38 & 192.71 & 201.01 & 447.39 \\
\hline Maize & 47.74 & 63.87 & 66.43 & 75.38 & 53.52 & 78.09 \\
\hline Rice & Millet & & & & & \\
\hline
\end{tabular}

Notes: See Table 2 for definition of TR0-TR5

Average profit for the 50-year average (2000-50), 2015 constant price

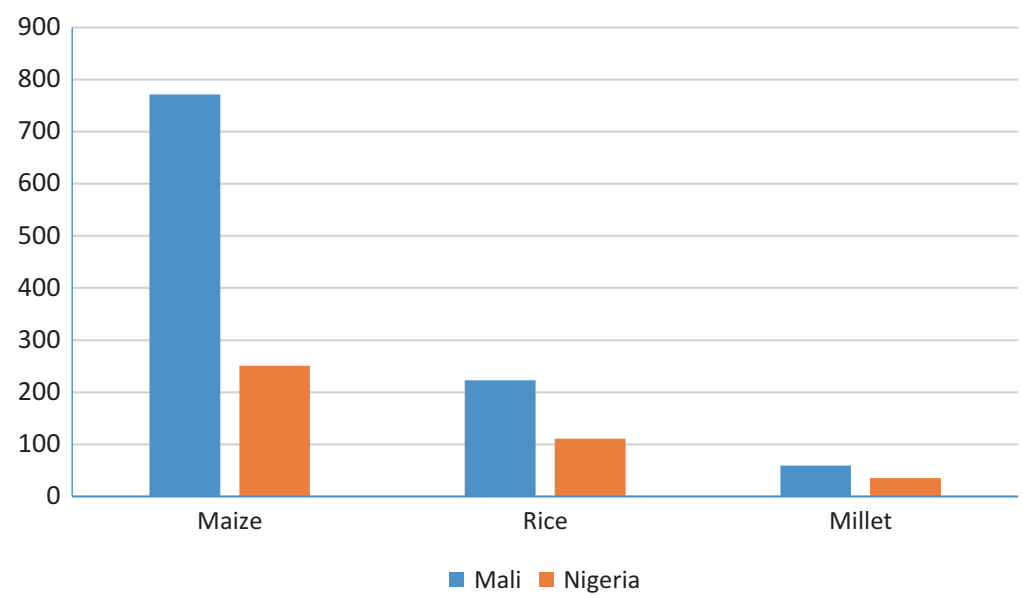

Fig. 6 Change of profit per ha due to a switch from farmer practice to ISFM

If a household switches from the farmer practice (TR0 \& TR1) to medium-level ISFM (TR3), their maize and rice profits are expected to more than double in both countries (Fig. 6) - suggesting that adoption of ISFM will simultaneously reduce poverty and production risks and increase food security.

As seen in Table 5, adoption rate of ISFM is low - despite its high returns. There are several reasons that contribute to this pattern and the econometric analysis below will shed light on this. However, a couple of factors need to be examined in detail since they may not be reflected fully in an econometric analysis.

(i) ISFM and OSFM practices are labor intensive: In all treatments using manure, labor costs amounted to $50-80 \%$ of total production costs. This is a major constraint for OSFM that includes a transfer of biomass - especially under SSA's low mechanization. Ownership of livestock is an important driver given that 


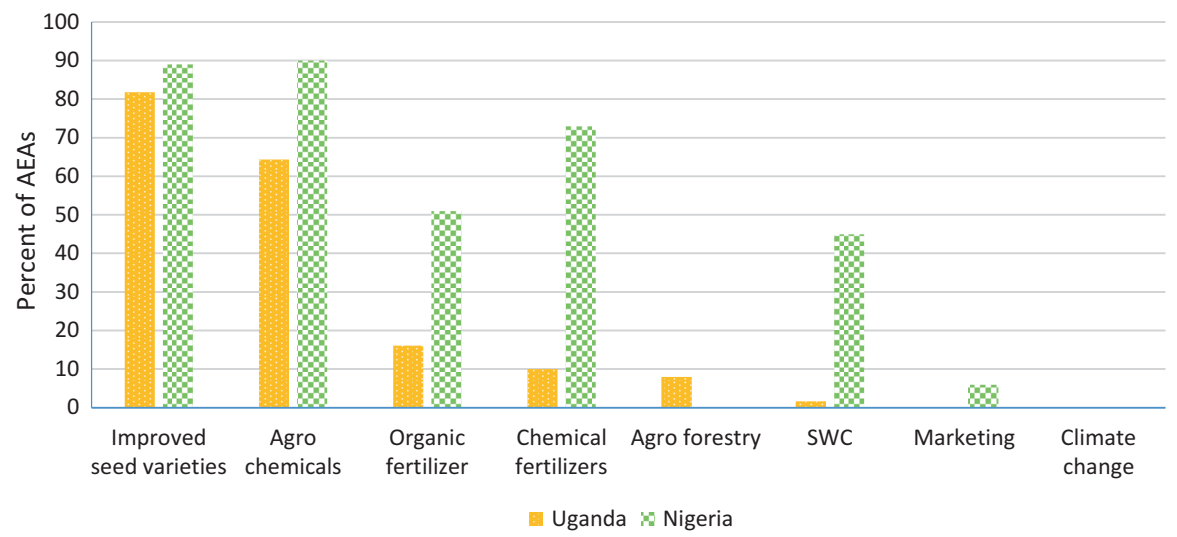

Fig. 7 Major topics promoted by AEAs in Nigeria and Uganda (Notes: AEAs Agricultural extension agents, SWC Soil and water conservation practices. Sources: Extracted from: Banful et al. (2010) - Nigeria results; Nkonya et al. (2013) - Uganda results)

there are no marketing mechanisms for organic inputs and that biomass transfer could require animal draft power. This means farmers need to produce their own organic inputs and must have transportation to move animal and household refuse from home to crop plots.

(ii) Low capacity of agricultural extension agents to provide advisory services on ISFM \& adaptation to climate change: Studies done in Nigeria and Uganda involving agricultural extension agents (AEAs) on topics they promote to farmers showed that improved seeds and agrochemicals are the most important technologies promoted (Fig. 7). Promotion of chemical fertilizers in Nigeria is high but limited in Uganda. Promotion of agroforestry and other organic inputs was quite low in both countries. No AEAs promoted agroforestry in Nigeria though $51 \%$ promoted organic fertilizer like manure. In both countries, no AEAs promoted climate change adaptation strategies. The results reflect the low capacity of AEAs to provide advisory services on OSFM and climate change.

Where average profit is given by:

$$
\Delta \pi \%=\frac{\pi_{I S F M}-\overline{\pi_{c}}}{\overline{\pi_{c}}} * 100
$$

Where $\Delta \pi=$ change in crop profit per ha, $\pi_{I S F M}=$ Profit with middle-level ISFM (40 $\mathrm{kgN} / \mathrm{ha}+1.7$ tons manure/ha, $50 \%$ crop residues, $\overline{\pi_{C}}=$ Average profit per ha for farmer practice, i.e., TR0 \& TR1.

The section below analyzes the drivers of adoption of SLWM by taking into account other factors. 


\subsection{Drivers of Adoption of SLWM Practices}

Human capital We find that in Mali, older farmers are more likely to use manure and ISFM while younger farmers are more likely to use inorganic fertilizer (Table 7). In Nigeria however, older farmers are more likely to use inorganic fertilizer (Table 8) - a reflection of older farmers' higher income and/or political influence that increase their access to subsidized fertilizer. The results in Mali suggest that for quick wins, fertilizer subsidy programs need to be targeted to younger farmers, who also happen to be poorer and - as observed in Ethiopia by Krishnan and Patnam (2014) - could serve as AEAs to other farmers. As demonstrated by Bandiera and Rasul (2006), and Conley and Udry (2010) young adopters of agricultural production technologies could influence other farmers decision to adopt new technologies through peer influence. The dependence ratio in Mali and Nigeria increases the propensity to use ISFM and inorganic fertilizer. This is likely driven by an attempt by households with a large number of children to increase per unit area production to address family food needs. Household size in Mali and Nigeria increases with adoption of ISFM and inorganic fertilizer in Mali. Family size also increases the propensity to use OSFM in Nigeria. This could be due to high family labor for large households allowing them to adopt labor intensive practices - especially those including biomass transfer.

Secondary and post-secondary education has a negative impact on propensity to adopt irrigation in Nigeria. Contrary to Di Falco (2014), level of formal education has no significant effect on probability to adopt any soil fertility management practice considered in Nigeria. This could be due to a small percent of households of the benchmark group - farmers with no formal education - who only constitute $10 \%$ of the sample population. In Mali, primary and secondary education increases adoption of manure. Similarly, secondary and post-secondary education increases adoption of inorganic fertilizer in Mali.

Female-headed households in Mali have greater propensity to adopt ISFM but the converse is the case in Nigeria. The greater likelihood of adoption of ISFM in Mali by female-headed households reflects their greater efficiency in utilizing labor and agricultural investments (Oladeebo and Fajuyigbe 2007). It is also a reflection of the higher and lower adoption rates of organic inputs in Mali and Nigeria respectively. In both countries, female-headed households are less likely to adopt irrigation. This is consistent with van Koppen et al. (2013) who found that the irrigation adoption rate of female headed households in SSA is only twothirds of the rate of male-headed households.

\subsubsection{Financial and Physical Capital}

As expected, access to credit increases probability to use inorganic fertilizer, ISFM, and irrigation in both countries (Tables 7 and 8). However, access to credit reduces propensity to adopt manure. This could be due to a substitution effect in that farmers 


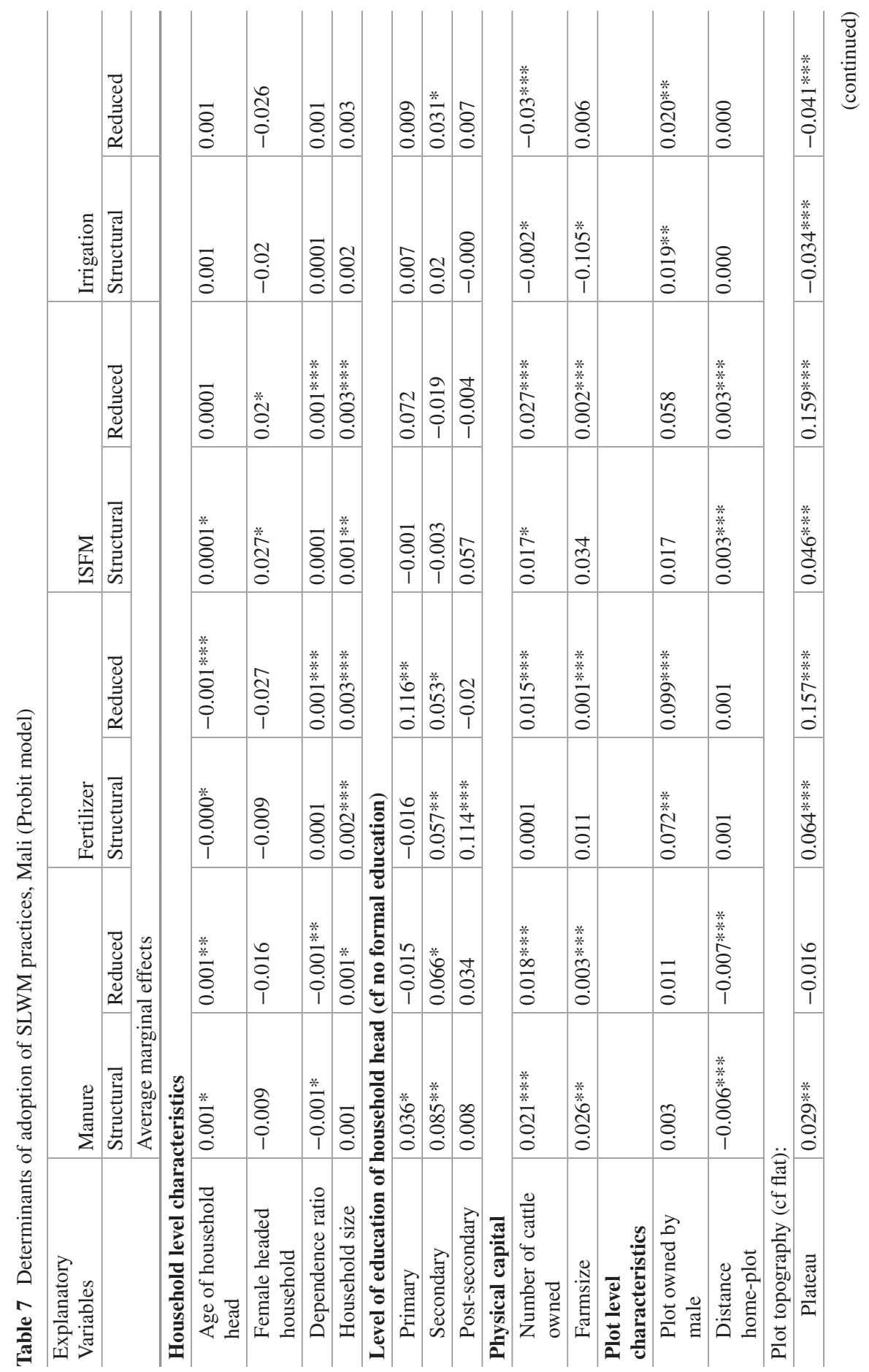




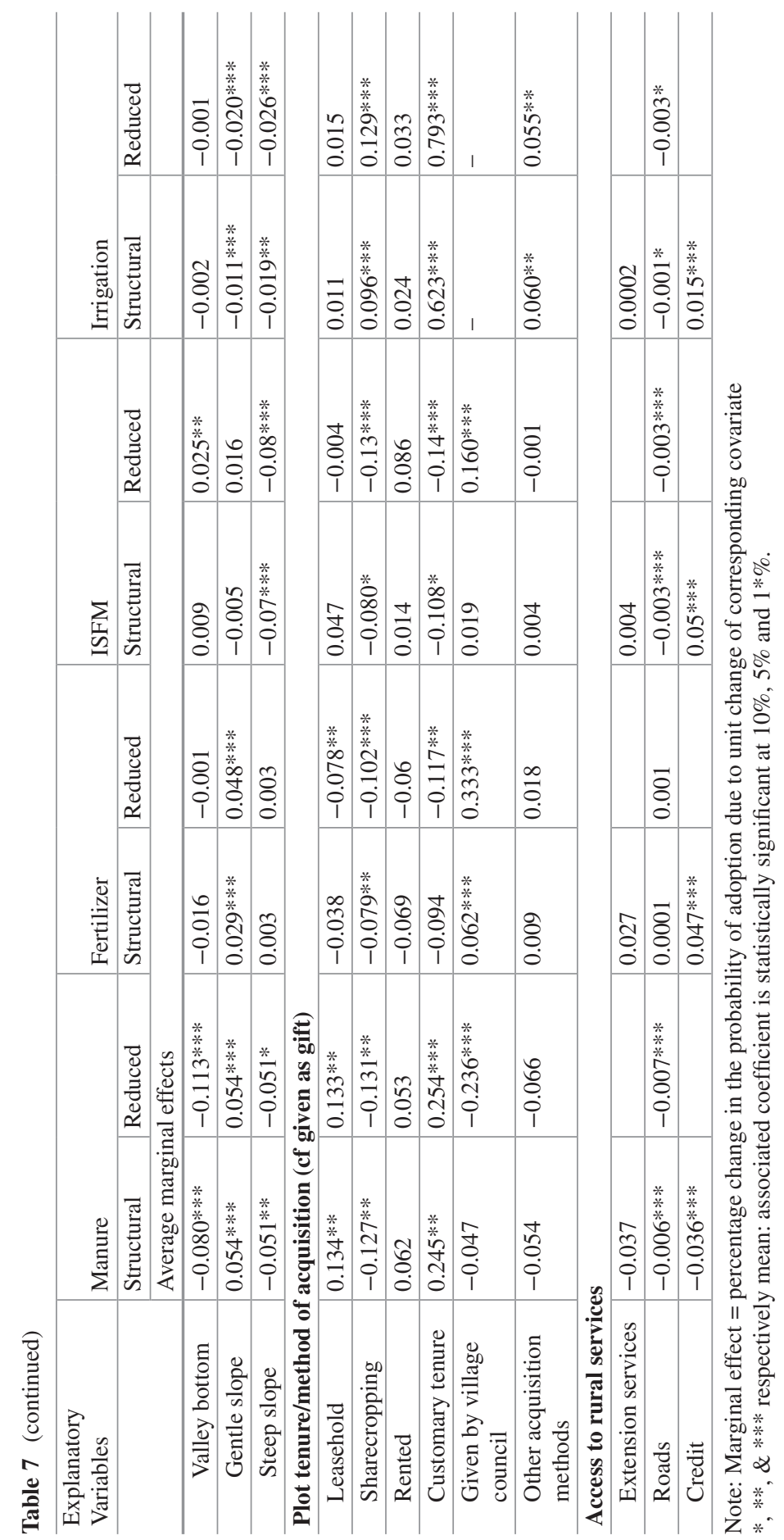




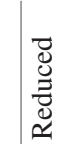

:

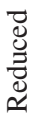

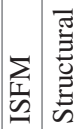

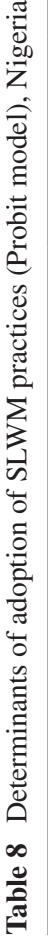

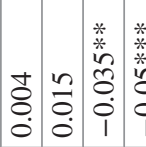

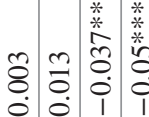

$\stackrel{*}{*} \underset{*}{*} \stackrel{8}{\circ}$

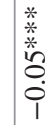

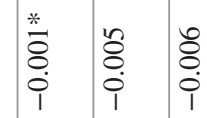

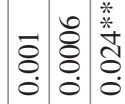

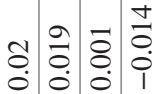

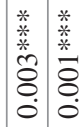

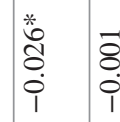

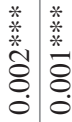

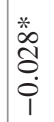

$\overline{8}$
0
0
$\overline{8}$
0
1

\begin{tabular}{l|l}
\hline & 0 \\
0 & 0 \\
0
\end{tabular}

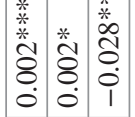

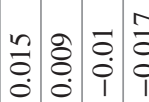

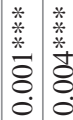

ڤై

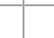

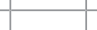

๑ิ

苞

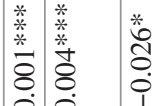

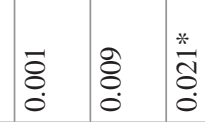

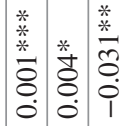

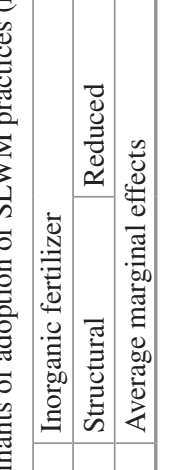

窇

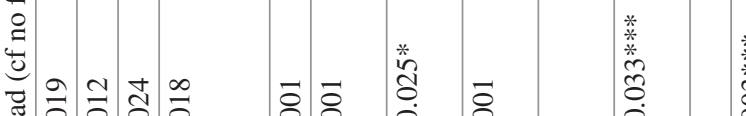

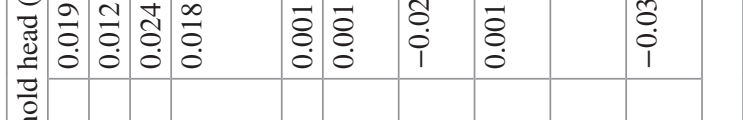

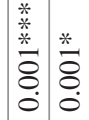

葛

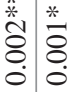

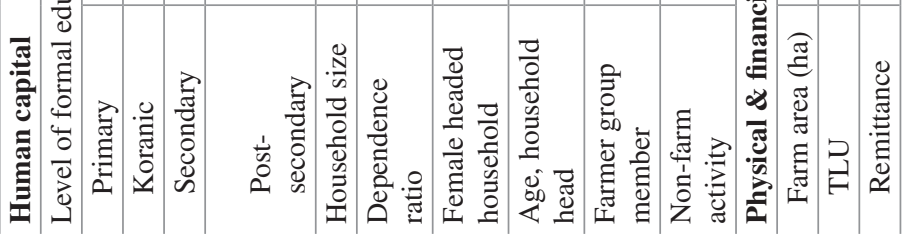




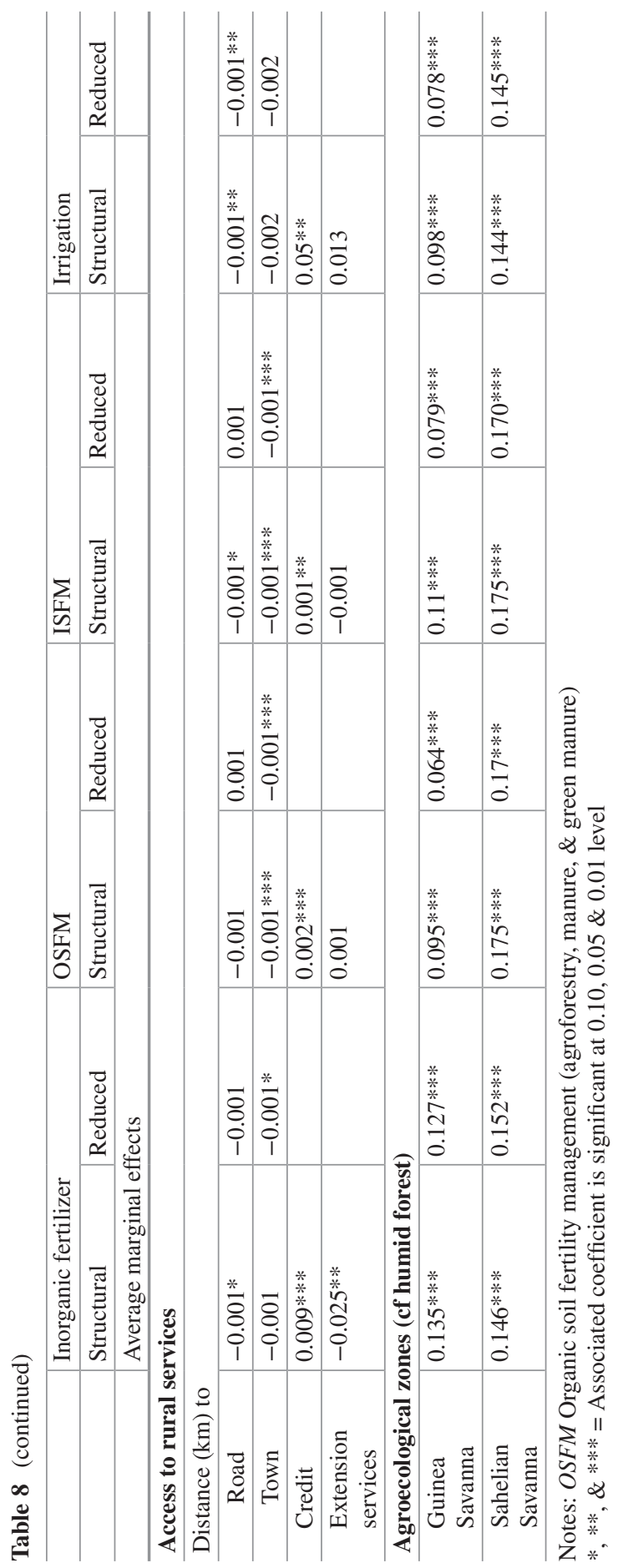


with access to credit substitute manure with fertilizer. The results suggest the importance of access to credit for adoption of purchased inputs and its role in adaptation to climate change. Remittances reduce the probability to use inorganic fertilizer and ISFM in Nigeria. This could be due to the fact that remittances are received in time of emergencies and not used for purchase of inputs.

Contrary to Di Falco (2014), access to extension services also has no significant impact on propensity to adopt soil fertility management practices in both countries. In fact extension services reduce probability to adopt manure. As discussed earlier, only a small share of AEAs promote OSFM practices (Fig. 7). Consistent with Di Falco (2014) and Barrett and Constas (2014), proximity to roads increases the propensity to irrigation in both countries. This is consistent with the theory that irrigated crops are marketed more than rainfed crops because irrigation involves large investments in equipment and infrastructure and use greater amounts of inputs for irrigated crops (You et al. 2011). Proximity to roads also increases the probability to use manure and ISFM in Mali. In Nigeria, proximity to roads and cities of more than 50,000 residents increases the probability to use all three soil fertility management practices considered. Consistent with Nelson et al. (2009), the results underscore the importance of market access for enhancing adaptation to climate change.

As expected, physical capital endowment (livestock and farm size) increases propensity to use fertilizer and ISFM in both countries but reduces the propensity to adopt irrigation in Mali. The inverse relationship between irrigation adoption and farm size is expected given that farmers in SSA irrigate small farms more than large ones (Domenech and Ringler 2013). The number of livestock owned also increases the probability to use manure in Mali - an aspect that underscores the lack of a market for OSFM that forces farmers to depend on their own production. The number of livestock is also inversely associated with the probability to use irrigation - an aspect that is expected given that pastoralists with large herds of cattle are less likely to be engaged in large investment crop production.

Of specific interest is the topography of plots, which is an indicator for irrigation use, and here analyzed in Mali only. ${ }^{6}$ Small scale irrigation is largely done on gentle slope plots because irrigation on steep slopes is difficult and expensive to implement (Nielsen et al. 2015). Accordingly, irrigation is more likely to be done on plots with flatter terrain than on any other topography (Table 7).

\subsection{Reducing Climate-Related Risks - The Role of Soil Carbon and SLWM Practices}

Soil carbon enhances soil moisture conservation and consequently reduces yield variability in areas with low-rainfall and highly variable moisture (Lal 2015; Govaerts et al. 2009; Manna et al. 2005). Consistent with this, our 30-year

\footnotetext{
${ }^{6}$ Plot topography data were not collected in Nigeria.
} 


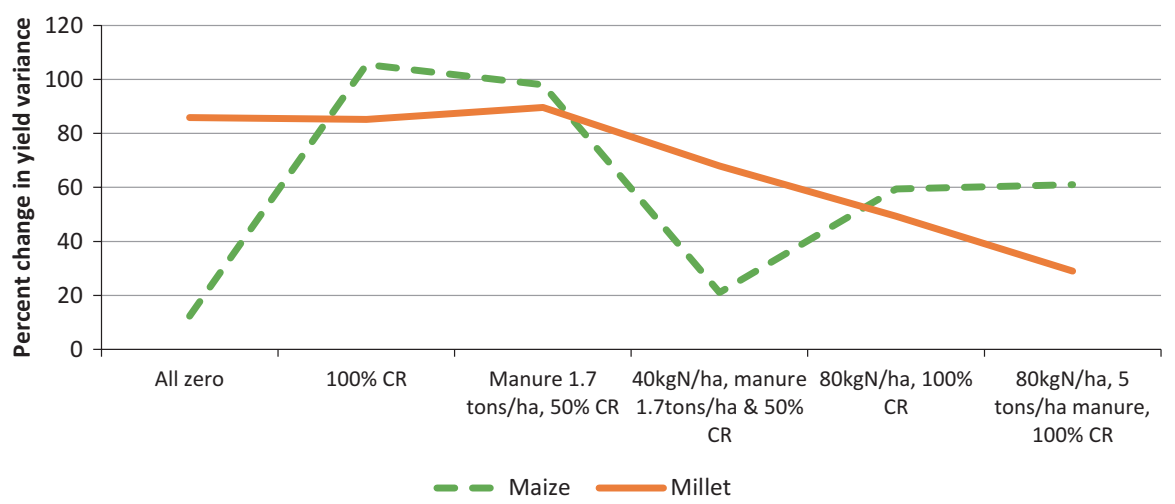

Fig. 8 Impact of SLWM on maize and millet yield variance - 30 year DSSAT simulation results, Mali

simulation results show that maize and millet yield variance in the dry areas of Mali fell as the amount of soil carbon increased (Fig. 8).

Accordingly, the Just-Pope mean-variance results show that almost all SLWM practices in both countries reduce production risks (Tables 9 and 10) - underscoring their importance in designing appropriate climate change adaptation strategies.

Other variables are also important in reducing climate-related production risks. Specifically, access to roads reduces production risks in both countries further demonstrating the role played by market access in adaptation to climate change. This supports Nelson et al. (2009) findings that two thirds of US\$3 billion additional investment required to offset climate change impacts on nutrition in SSA will need to be directed to roads (Fig. 1). Similarly, irrigation is associated with lower production risks in both countries.

Rainfed area also reduces production risks. This could be due to largescale farmers' ability to invest in management practices that could lead to reduction of production risks. The number of livestock is a risk reducing asset in both countries. This underscores the role played by livestock in risk management through organic soil fertility improvement and provision of animal power for biomass transfer.

Post-primary education in Mali reduces production risks - underscoring the key role of human capital in adaptation to climate change. Like the case of adoption of SLWM however, education does not have a significant impact on production risks in Nigeria. 
Table 9 Impact of SLWM practices on climate-related production risks - Just-Pope meanvariance model, Mali

\begin{tabular}{|c|c|}
\hline Explanatory variables & Variance Function, (FGLS) \\
\hline SLWM practices: & Ln(crop value $\mathrm{XOF})^{2}$ \\
\hline Manure & $-0.084 * * *$ \\
\hline Inorganic fertilizer & $-0.131 * * *$ \\
\hline ISFM & $-0.005^{* * *}$ \\
\hline \multicolumn{2}{|l|}{ Human capital } \\
\hline (Ln(age of household head) & $0.094 * * *$ \\
\hline Male-headed household head & $-0.185^{* *}$ \\
\hline Dependence ratio & $0.001 * *$ \\
\hline Ln(Family size) & $-0.023 * *$ \\
\hline \multicolumn{2}{|c|}{ Level of education of household head (cf no formal education) } \\
\hline Primary & -0.016 \\
\hline Secondary & $-0.605 * * *$ \\
\hline Post-secondary & $-0.508 * *$ \\
\hline \multicolumn{2}{|l|}{ Physical endowment } \\
\hline TLU & $-0.087 * * *$ \\
\hline Access to credit & $1.58 * * *$ \\
\hline \multicolumn{2}{|l|}{ Access to rural services } \\
\hline Access to extension services & -0.112 \\
\hline $\mathrm{Ln}($ distance to road, $\mathrm{km})$ & $-0.030 * *$ \\
\hline \multicolumn{2}{|l|}{ Plot level characteristics } \\
\hline Plot owned by male & 0.373 \\
\hline Ln(Distance $(\mathrm{km})-$ homestead to plot $)$ & $-0.019 * *$ \\
\hline \multicolumn{2}{|l|}{ Slope position (cf flat) } \\
\hline Plateau & $-0.023 * *$ \\
\hline Valley bottom & $-0.078 * *$ \\
\hline Gentle slope & $0.003 * * *$ \\
\hline Steep slope & $-0.026 * * *$ \\
\hline Constant & $-0.294 * * *$ \\
\hline
\end{tabular}

Note: FGLS feasible generalized least squares

$*, * *, \& * * *$ means associated coefficient is statistically significant at $0.10,0.05 \& 0.01$ confidence interval

\section{Conclusions and Policy Implications}

Our estimates show that climate change is predicted to reduce production of staple foods (maize, rice, and millet) by about $20 \%$ by 2050 if farmers do not take adaptive strategies. This jeopardizes food security - especially for the poorest farmers who 
Table 10 Impact of SLWM practices on climate-related production risks - Just-Pope meanvariance model, Nigeria

\begin{tabular}{|c|c|}
\hline & Variance model (FGLS) \\
\hline \multicolumn{2}{|l|}{ SLWM practices } \\
\hline Irrigation & $-0.009 * * *$ \\
\hline Soil bunds & $-0.613 * * *$ \\
\hline Stone bunds & $-0.843 * * *$ \\
\hline Mulching & 0.248 \\
\hline Grass strip & $-0.592 * * *$ \\
\hline Ditches & $-0.715^{* * *}$ \\
\hline Ridges & $-0.272 * * *$ \\
\hline Animal manure & 0.13 \\
\hline Compost & $-0.427 * * *$ \\
\hline Inorganic fertilizer & $-0.139 * *$ \\
\hline ISFM & $-0.134 * *$ \\
\hline \multicolumn{2}{|l|}{ Human capital } \\
\hline Ln(Age of household head) & 0.034 \\
\hline Ln(number of adult males) & -0.055 \\
\hline Ln(adult females) & -0.065 \\
\hline Female household head & 0.062 \\
\hline \multicolumn{2}{|c|}{ Education of household head (cf no formal education) } \\
\hline Primary & 0.044 \\
\hline Koranic & 0.114 \\
\hline Secondary & 0.001 \\
\hline Post-secondary & -0.098 \\
\hline \multicolumn{2}{|l|}{ Physical and financial capital } \\
\hline Remittance & $-0.157 * * *$ \\
\hline Ln(value of productive) assets) & $-0.023 * *$ \\
\hline $\operatorname{Ln}(\mathrm{TLU})$ & $-0.025^{*}$ \\
\hline Ln(rainfed area) & $-0.177 * * *$ \\
\hline \multicolumn{2}{|l|}{ Access to rural services } \\
\hline $\mathrm{Ln}($ distance to market, $\mathrm{km})$ & 0.021 \\
\hline $\mathrm{Ln}($ distance to road, $\mathrm{km})$ & $-0.032 *$ \\
\hline \multicolumn{2}{|c|}{ Agroecological zones (cf Sahelian Savannah) } \\
\hline Humid forest & $1.101 * * *$ \\
\hline Guinea Savannah & $0.192 * * *$ \\
\hline Constant & $1.470 * * *$ \\
\hline
\end{tabular}

Note: $F G L S$ feasible generalized least squares

$*, * *, \& * * *$ means associated coefficient is statistically significant at $0.10,0.05 \& 0.01$ confidence

heavily depend on rainfed agriculture and who do not use soil carbon-enhancing management practices. Our results show that even though all land management practices considered lead to a lower yield due to climate change, adoption of SLWM practices could completely offset the negative effect of climate change on crop production related to farmer management practices and significantly reduce production risks. Specifically, adoption of SLWM will simultaneously increase crop yield and 
profit under current farmer practice by at least twofold. This means SLWM could simultaneously increase food security and reduce poverty and climate-related production risks. This is in addition to the off-site benefit of carbon sequestration, which farmers do not consider in their planning. This underscores the importance of promoting SLWM practices to help smallholder farmer adaptation and resilience to climate change and to help SSA countries to achieve their commitment to the UNFCCC 21st Conference of Parties (CO21) to contribute to the reduction of GHG emissions.

The low adoption rate of SLWM calls for major changes in the agricultural development policies and strategies.

The major drivers for adoption of SLWM include access to agricultural extension services, market access, credit, and greater endowment of physical resources. The results underscore the need for increasing access to rural services - especially for farmers in remote areas and poor farmers and female-headed households. Improvement of market access will provide incentives for farmers to use SLWM and other production technologies. Development of market infrastructure could serve multiple purposes of rural poverty reduction and modernization of agriculture. This could be done in conjunction with other rural development and poverty reduction programs. This demonstrates that adaptation to climate change will need to be more holistic and go beyond the traditional approach of compartmentalized development strategies.

There is need for increasing the training of agricultural extension service providers about SLWM and climate change - both of which are relatively new to many older agricultural extension services. Additionally, advisory services on irrigation development and management remain weak. This is especially true for irrigation engineering advisory services, which remain largely confined to large-scale irrigation schemes (Nkonya et al. 2015b). As a result of this and other factors, water loss in irrigation schemes and irrigation systems is more than 50\% in Africa (Delaney 2009). Short-term training with specific focus on these important topics will be more effective and practical than long-term training. Additionally, sex of extension agent providers has a large impact on type of advisory services provided and beneficiaries of such services (Takeshima and Edeh 2013; Davis et al. 2012). Our results show that female-headed households are less likely to adopt SLWM. One strategy for increasing their adoption is to recruit more female extension agents who are better able to provide advisory services and SLWM messages to women than male extension agents (Nkonya et al. 2013; Davis et al. 2012; Takeshima and Edeh 2013).

The challenges of adoption of SLWM also includes high labor intensity of practices which involves biomass transfer, limited marketing infrastructure, and production of organic inputs like manure. Promotion of agroforestry is likely to be an amenable practice since it is less labor intensive once it gets established and it simultaneously addresses both lack of markets and production challenges of organic inputs. Unfortunately, current soil fertility management policies gravitate around inorganic fertilizer subsidy. There are no programs that provide incentives for adoption of OSFM practices like agroforestry. Given the multiple benefits of OSFM practices, it is important to consider initiatives that provide incentives for adoption of agroforestry, ISFM, and OSFM practices. For example, it is possible to provide 
conditional fertilizer subsidies given to beneficiaries who have planted trees in croplands. Such incentives are easy to verify and could serve as a form of payment for ecosystem services since they will increase carbon sequestration. A study in Malawi showed that farmers are highly receptive to conditional fertilizer subsidies given to farmers to plant agroforestry trees (Marenya et al. 2014).

Following UNFCCC's COP21 resolution to include agriculture in the carbon sequestration program, adaptation and mitigation in the agricultural sector is included in $80 \%$ of the national INDCs (Richards et al. 2015). This provides a unique opportunity for building carbon markets in SSA by organizing smallholder land users to participate in the carbon market. This could be effectively achieved by organizing them in groups and giving them the mandate to manage their natural resources. Implementing this would require revision of the Decentralization Act in order to give villagers a full mandate to manage their own resources. Efforts to increase economic interest groups and cooperatives would also help smallholder land users to work collectively. Success of carbon markets is greater when both international and domestic buyers are involved. The domestic buyers could include governments. Additionally, experience has shown that the payment for ecosystem services (PES) are successful in countries with strong policies and investment in PES. For example, the Costa Rica constitution sets a framework for rewarding land users who provide significant offsite benefits (Salazar and Chacón 2011). The constitution further states that revenue collected from fossil fuel taxes, water fees, and from donors be allocated to PES (Ibid). The land users also are exempted from paying some local taxes. These incentives have significantly helped to combat deforestation in Costa Rica. This suggests that the governments in SSA need to enhance their policies that enhance incentives of land users to adopt ISFM and OSFM practices.

The impact of climate change on food security and rural development in general are large and require immediate action to offset their effects on the rural poor. The opportunities for addressing climate risks using SLWM are large but they need strong government commitment to exploit them in order to achieve food security and ensure sustainable agricultural development in Africa.

Acknowledgement We are grateful to the TerrAfrica World Bank for providing funding for this study. We are also grateful to the farmers and community leaders in Mali and Nigeria who provided data and information used in this study. We thank ministries of agriculture and environment as well research institutions and bureaus of statistics from both countries for providing data and documents. We are indebted to a number of colleagues from the World Bank and participants to various workshops who provided insightful comments to various versions of this paper. We are also grateful to Taoufiq Bennouna, Stephen Danyo, and Florence Richard who managed this study project from the World Bank. The authors take responsibility for all errors and omissions of this report. 


\section{References}

Aduayi, E. A., Chude, V. O., Adebusuyi, B. A., \& Olayiwola, S. O. (2002). Fertilizer use and management practices for crops in Nigeria. Federal Ministry of Agriculture and Rural Development Abuja, Nigeria P, 63-65.

AU (African Union). 2014. Malabo declaration on accelerated agricultural growth and transformation for shared prosperity and improved livelihoods. Online at http://www.au.int/en/content/ malabo-26-27-june-2014-decisions-declarations-and-resolution-assembly-union-twenty-thirdord. Accessed on August 25, 2015.

Bandiera, O., \& Rasul, I. (2006). "Social networks and technology adoption in northern Mozambique." The Economic Journal, 116(514):869-902.

Banful A.B., E. Nkonya and V. Oboh. 2010. Constraints to Fertilizer Use in Nigeria Insights from Agricultural Extension Service. IFPRI Discussion Paper 01010.

Barrett, C. B., \& Constas, M. A. (2014). Toward a theory of resilience for international development applications. Proceedings of the National Academy of Sciences, 111(40), 14625-14630.

Benin, S. and Yu, B. 2012. Complying the Maputo Declaration Target: trends in public agricultural expenditures and implications for pursuit of optimal allocation of public agricultural spending. ReSAKSS Annual Trends and Outlook Report 2012. International Food Policy Research Institute (IFPRI).

Burney, J. A., Naylor, R. L., \& Postel, S. L. (2013). The case for distributed irrigation as a development priority in sub-Saharan Africa. Proceedings of the National Academy of Sciences, 110(31), 12513-12517.

Christensen, J. H., B. Hewitson, A. Busuioc, A. Chen, X. Gao, I. Held, R. Jones, et al. 2007. "Regional Climate Projections." In Climate Change 2007: The Physical Science Basis. Contribution of Working Group I to the Fourth Assessment Report of the Intergovernmental Panel on Climate Change. In: Solomon S., D. Qin, M. Manning, Z. Chen, M. Marquis, K. B. Averyt, M. Tignor, et al. (eds), 847-940. Cambridge, UK: Cambridge University Press.

Conley, T. and C. Udry (2010). "Learning about a New Technology." American Economic Review, 100(1):35-69.

Davis, K., Nkonya, E., Kato, E., Mekonnen, D. A., Odendo, M., Miiro, R., \& Nkuba, J. (2012). Impact of farmer field schools on agricultural productivity and poverty in East Africa. World Development, 40(2), 402-413.

Delaney S. 2009. Challenges and opportunities for agricultural water management in West and Central Africa: Lessons from IFAD experience. IFAD, Rome.

Di Falco S. 2014. Adaptation to climate change in Sub-Saharan agriculture: assessing the evidence and rethinking the drivers. European Review of Agricultural Economics 41 (3): 405-430.

Dillon, A. (2008). Access to irrigation and the escape from poverty: Evidence from northern. International Food Policy Research Institute Discussion paper 782.

Doraiswamy P, McCarty G, Hunt E, Yost R, Doumbia M, Franzluebbers A (2007) Modeling soil carbon sequestration in agricultural lands of Mali. Agricultural Systems 94(1):63-74

Domenech, L., \& Ringler, C. (2013). The impact of irrigation on nutrition, health, and gender: A review paper with insights for Africa south of the Sahara. International Food Policy Research Institute (FPRI) Discussion paper \#1428

Fabricius C., A. Ainslie, J. Cloete, C. Shackleton, S. Shackleton, P. Urquhart, J. Gambiza, E. Nel, K. Rowntree, M. Mortimore, J. Ariyo, M. Bila, A. Faye, A. Faye, S. Herrmann, S. Mohammed, H. Seyni, K. Vogt, B. Yamba, S. Herrmann, S. Maddrell, C. Nzioka and I. Bond. 2008. Situation Analysis of Ecosystem Services and Poverty Alleviation in arid and semi-arid Africa. Ecosystem Services for Poverty Alleviation (ESPA) report. Online at http://www.nerc.ac.uk/ research/funded/programmes/espa/final-report-africa/ accessed December 22, 2015.

FAO (2005). Irrigation in Africa in figures. AQUASTAT Survey - 2005. FAO Water Report \# 29. Online at ftp://ftp.fao.org/agl/aglw/docs/wr29_eng.pdf. Accessed on December 22, 2015.

FAO (Food and Agriculture Organization). 2005a. Mali Livestock sector Brief. FAO, Rome

FAO (Food and Agriculture Organization). 2005b. Nigeria Livestock sector Brief. FAO, Rome

FAO (Food and Agriculture Organization). 2005c. Nigeria Water Report. Water Report 29. Online at http://www.fao.org/nr/water/aquastat/countries_regions/nga/index.stm 
FAO (Food and Agriculture Organization). 2012. The State Of Food and Agriculture, 2012. Investing in Agriculture. FAO, Rome.

Gijsman, A. J., Hoogenboom, G., Parton, W. J., \& Kerridge, P. C. (2002). Modifying DSSAT crop models for low-input agricultural systems using a soil organic matter-residue module from CENTURY. Agronomy Journal, 94(3), 462-474.

FAOSTAT (2013). Agricultural statistics. Online at http://www.fao.org/faostat/en/\#data. Accessed on January 12, 2017.

Govaerts, B., N. Verhulst, A. Castellanos-Navarrete, K.D. Sayre, J. Dixon, \& L. Dendooven, (2009). Conservation agriculture and soil carbon sequestration: between myth and farmer reality. Critical Reviews in Plant Science, 28(3):97-122.

Hijmans, R.J., S.E. Cameron, J.L. Parra, P.G. Jones and A. Jarvis, 2005. Very high resolution interpolated climate surfaces for global land areas. International Journal of Climatology 25: 1965-1978

Höhne, N., Ellermann, C., \& Li, L. (2014). Intended Nationally Determined Contributions under the UNFCCC. Ecofys Discussion paper. Cologne: Ecofys. Online at http://mitigationpartnership.net/sites/default/files/u1585/discussion-paper-indcs.pdf. Accessed on August 23, 2015.

Hoogenboom, G., J.W. Jones, P.W. Wilkens, C.H. Porter, K.J. Boote, L.A. Hunt, U. Singh, J.L. Lizaso, J.W. White, O. Uryasev, F.S. Royce, R. Ogoshi, A.J. Gijsman, and G.Y. Tsuji. 2010. Decision Support System for Agrotechnology Transfer (DSSAT) Version 4.5 [CD-ROM]. University of Hawaii, Honolulu, Hawaii.

INS (Institut National de la Statistique du Mali, Mali). 2009. 2009 Census data. Online at http:// www.instat-mali.org/ Accessed on August 23, 2015.

IPCC (Intergovernmental Panel on Climate Change). 2007. Summary for policymakers. Climate change 2007: the physical science basis. Working Group I Contribution to IPCC Fourth Assessment Report: Climate Change 2007, Geneva

Jahnke, H.E. (1982). Livestock Production Systems and Livestock Development in Tropical Africa, Kiel.

Johnson, M., Takeshima, H., \& Gyimah-Brempong, K. (2013). Assessing the potential and policy alternatives for achieving rice competitiveness and growth in Nigeria. IFPRI Discussion Paper \#01301.

Jones, J.W., G. Hoogenboom, C.H. Porter, K.J. Boote, W.D. Batchelor, L.A. Hunt, P.W. Wilkens, U. Singh, A.J. Gijsman, and J.T. Ritchie. 2003. DSSAT Cropping System Model. European Journal of Agronomy 18:235-265.

Just, R., \& Pope, R. D. (1979). Production function estimation and related risk considerations. American Journal of Agricultural Economics, 61(2), 276-284.

Kamuanga M.J.B., J. Somda, Y. Sanon, and H. Kagoné. 2008. Livestock and regional market in the Sahel and West Africa Potentials and challenges. Online at http://www.oecd.org/swac/publications/41848366.pdf, accessed August 21, 2015.

Kassie, M., H. Teklewold, P. Marenya, M. Jaleta, \& O. Erenstein. 2015. Production risks and food security under alternative technology choices in Malawi: Application of a multinomial endogenous switching regression. Journal of Agricultural Economics, 66(3):640-659.

Krishnan, P., \& M. Patnam. (2014). Neighbors and extension agents in Ethiopia: Who matters more for technology adoption? American Journal of Agricultural Economics, 96(1):308-327.

Lal R. 2015. Soil carbon sequestration and aggregation by cover cropping. Journal of Soil And Water Conservation 70(6):329-339.

Lal, R. (2004). Soil carbon sequestration to mitigate climate change. Geoderma, 123(1), 1-22.

Lal, R. (2011). Sequestering carbon in soils of agro-ecosystems. Food Policy, 36, S33-S39.

Leakey, A. D. (2009). Rising atmospheric carbon dioxide concentration and the future of C4 crops for food and fuel. Proceedings of the Royal Society of London B: Biological Sciences, rspb-2008:1-11.

Liniger, H., \& Critchley, W. (2007). Where the land is greener. Bern, Switzerland: CTA, FAO, UNEP, CDE on behalf of the World Overview of Conservation Approaches and Technologies (WOCAT).

Manna, M. C., Swarup, A., Wanjari, R. H., Ravankar, H. N., Mishra, B., Saha, M. N., ... \& Sarap, P. A. (2005). Long-term effect of fertilizer and manure application on soil organic carbon storage, soil quality and yield sustainability under sub-humid and semi-arid tropical India. Field crops research, 93(2), 264-280.

Marenya, P., Smith, V. H., \& Nkonya, E. (2014). Relative Preferences for Soil Conservation Incentives among Smallholder Farmers: Evidence from Malawi. American Journal of Agricultural Economics, 96(3):690-710. 
Ministère de l'Agriculture (2009). Bilan de la Campagne Agricole de l'Initiative Riz (2008-2009). Secrétariat Général, Ministère de l'Agriculture, République du Mali. Bamako, Mali.

Moussa, B., Nkonya, E., Meyer, S., Kato, E., Johnson, T., \& Hawkins, J. (2016). Economics of land degradation and improvement in Niger. In Economics of Land Degradation and Improvement-A Global Assessment for Sustainable Development (pp. 499-539). Springer International Publishing.

Nazlioglu, S., \& Soytas, U. (2012). Oil price, agricultural commodity prices, and the dollar: A panel cointegration and causality analysis. Energy Economics, 34(4), 1098-1104.

NBS (National Bureau of Statistics). 2012. Annual Abstract of Statistics, 2012

Nelson, G. C., Rosegrant, M. W., Koo, J., Robertson, R., Sulser, T., Zhu, T. Ringler, C. Msangi, S. Palazzo, A. Batka, M. Magalhaes, M. Valmonte-Santos, R. Ewing, M. Lee D. (2009). Climate change: Impact on agriculture and costs of adaptation (Vol. 21). Intl Food Policy Research Institute. Washington DC

Nielsen T., F. Schünemann, E. McNulty, M. Zeller, E.M. Nkonya, E. Kato, S. Meyer, W. Anderson, T. Zhu, A. Queface, L. Mapemba. 2015. The food-energy-water security nexus: Definitions, policies, and methods in an application to Malawi and Mozambique. IFPRI Discussion paper \#01480 pp. 71.

Dixon, J. A., Gibbon, D. P., \& Gulliver, A. (2001). Farming systems and poverty: improving farmers' livelihoods in a changing world. Food \& Agriculture Organization.

Nkonya E., H. Takeshima, T. Johnson, L. You, H. Xie, M. Adesugba, E. Kato, J. Ogbe, A. Madukwe, and T. Edeh. 2015b. Turning Tragedy into Opportunity: Water Management Solutions for Flood Recession and Dry Season Farming in Nigeria. IFPRI mimeo.

Nkonya E., Kwapong N.A., B. Bashaasha, M. Mangheni and E. Kato. 2013. Effectiveness of pluralistic and demand-driven and versus supply-driven agricultural extension services in Africa: Which reaches more farmers and women? The case of Uganda. IFPRI mimeo.

Nkonya E., T. Johnson, H.Y. Kwon, and E. Kato. 2016a. Economics of land degradation in subSaharan Africa In: E. Nkonya, A. Mirzabaev and J. von Braun (eds). Economics of Land Degradation and Improvement - A Global Assessment for Sustainable Development. Springer, New York: 215-260.

Nkonya, E., Anderson, W., Kato, E., Koo, J., Mirzabaev, A., von Braun, J., \& Meyer, S. (2016b). Global cost of land degradation. In Economics of Land Degradation and Improvement-A Global Assessment for Sustainable Development (pp. 117-165). Springer International Publishing, New York.

Nkonya, E., Place, F., Kato, E., \& Mwanjololo, M. (2015a). Climate risk management through sustainable land management in Sub-Saharan Africa. In Sustainable Intensification to Advance Food Security and Enhance Climate Resilience in Africa (pp. 75-111). Springer International Publishing.

Nkonya, E., J. Pender, E. Kato. 2008. "https://www.cambridge.org/core/journals/environmentand-development-economics/article/who-knows-who-cares-the-determinants-of-enactmentawareness-and-compliance-with-community-natural-resource-management-regulations-inuganda/011594149EC749785A2614DCBC6600BA" Who knows who cares? Determinants of enactment, awareness and compliance with community natural resource management regulations in Uganda." Environment and Development Economics 13(1):79-109.

Oladeebo, J. O., \& Fajuyigbe, A. A. (2007). Technical efficiency of men and women upland rice farmers in Osun State, Nigeria. Journal of Human Ecology, 22(2): 93-100.

Pender, J., Ringler, C., Magalhaes, M., \& Place, F. (2009). The role of sustainable land management for climate change adaptation and mitigation in sub-Saharan Africa. TerrAfrica.

RDM (Republique du Mali). 2007. Government Programme d'Action National d'Adaptation aux Changements Climatique.

RDM (Republique du Mali). 2009. National Strategy for the Development of Rice Growing. Online at http://www.jica.go.jp/english/our_work/thematic_issues/agricultural/pdf/mali_en.pdf

Richards M, Bruun TB, Campbell B, Gregersen LE, Huyer S, Kuntze V, Madsen STN, Oldvig MB, Vasileiou I. 2015. How countries plan to address agricultural adaptation and mitigation: An analysis of Intended Nationally Determined Contributions. CCAFS Info Note. Copenhagen, Denmark: CGIAR Research Program on Climate Change, Agriculture and Food Security (CCAFS). http://bit.ly/1Yfsotb 
Ringler C. and E. Nkonya. 2012. Sustainable land and water management policies. In Lal R. and B. Stewart (eds). Soil Water and Agronomic Productivity. Advances in soil science. CRC Press Taylor Francis Group, New York: 523-538.

Salazar M.C. and M.P. Chacón. 2011. The case of Costa Rica. In: Greiber T. and Simone Schiele (Eds.). Governance of Ecosystem Services. Gland, Switzerland: IUCN. xii + 140 pp

Sauer, J., Tchale, H., \& Wobst, P. (2007). Alternative soil fertility management options in Malawi: an economic analysis. Journal of Sustainable Agriculture, 29(3), 29-53.

Schlenker, W., \& Lobell, D. B. (2010). Robust negative impacts of climate change on African agriculture. Environmental Research Letters, 5(1), 014010.

Takeshima, H. and Edeh, H. (2013), Typology of Farm Households and Irrigation Systems: Some Evidence from Nigeria, IFPRI Discussion Paper 01267. International Food Policy Research Institute, Washington D.C.

Torero, M. (2015). Consistency between Theory and Practice in Policy Recommendation by International Organizations for Extreme Price and Extreme Volatility Situations.

UNDP (United Nations Development Program). 2015. Human Development Report 2015. Work for Human Development. UNDP, New York.

UNFCCC. 2015a. Adoption of the Paris Agreement. United Nations, New York.

UNFCCC. 2015b. INDC submissions. Available at http://www4.unfecc.int/submissions/INDC/ Submission\%20Pages/submissions.aspx. Accessed on August 23, 2015.

United Nations Framework Convention on Climate Change (UNFCCC). 2014a. "National Adaptation Programmes of Action Received by the Secretariat."

United Nations Framework Convention on Climate Change (UNFCCC). 2014b. "Appendix II Nationally Appropriate Mitigation Actions of Developing Country Parties." Online at http:// unfccc.int/meetings/cop_15/copenhagen_accord/items/5265.php. Accessed on August 23, 2015.

van Koppen, B., Hope, L., \& Colenbrander, W. (2013). Gender aspects of small-scale private irrigation in Africa International Water Management Institute (IWMI) Working Paper \# 1543.

Vanlauwe B., K. Descheemaeker, K. E. Giller, J. Huising, R. Merckx, G. Nziguheba, J. Wendt, and S. Zingore. 2015. Integrated soil fertility management in sub-Saharan Africa: unravelling local adaptation. Soil, 1:491-508.

World Bank. 2014. World Development Report, 2014. Risk and Opportunity Managing Risk for Development. World Bank, Washington DC., 344pp

World Bank. 2015. World Development raw database. Online at http://databank.worldbank.org/ data/reports.aspx?source=world-development-indicators. Accessed January 14, 2017.

Zseleczky, L., \& Yosef, S. (2014). Are shocks becoming more frequent or intense? Resilience for Food and Nutrition Security, 9.

Open Access This chapter is distributed under the terms of the Creative Commons AttributionNonCommercial-ShareAlike 3.0 IGO license (https://creativecommons.org/licenses/by-nc-sa/3.0/ igo/), which permits any noncommercial use, duplication, adaptation, distribution, and reproduction in any medium or format, as long as you give appropriate credit to the Food and Agriculture Organization of the United Nations (FAO), provide a link to the Creative Commons license and indicate if changes were made. If you remix, transform, or build upon this book or a part thereof, you must distribute your contributions under the same license as the original. Any dispute related to the use of the works of the FAO that cannot be settled amicably shall be submitted to arbitration pursuant to the UNCITRAL rules. The use of the FAO's name for any purpose other than for attribution, and the use of the FAO's logo, shall be subject to a separate written license agreement between the FAO and the user and is not authorized as part of this CC-IGO license. Note that the link provided above includes additional terms and conditions of the license.

The images or other third party material in this chapter are included in the chapter's Creative Commons license, unless indicated otherwise in a credit line to the material. If material is not included in the chapter's Creative Commons license and your intended use is not permitted by statutory regulation or exceeds the permitted use, you will need to obtain permission directly from the copyright holder. 